\title{
A RARE CASE OF SAUROPHAGY BY SCOLOPENDRA CINGULATA (CHILOPODA: SCOLOPENDRIDAE) IN THE CENTRAL AEGEAN ARCHIPELAGO: A ROLE FOR INSULARITY?
}

\author{
Aris Deimezis-Tsikoutas*, Grigoris Kapsalas and Panayiotis Pafilis
}

Section of Zoology and Marine Biology, Faculty of Biology, School of Science, National and Kapodistrian University of Athens, Panepistimiopolis 15701, Athens, Greece

*Corresponding author. Email: adeime@biol.uoa.gr

\author{
Article history \\ Received: 12 March 2020; \\ accepted 28 April 2020
}

Keywords:

Centipedes; Mediterranean;

Podarcis erhardii;

predation; Scolopendra

cingulata; Scolopendridae

\begin{abstract}
Centipedes feed mainly on insects and other invertebrates. However, they may occasionally enhance their diet with small vertebrates. Lizard consumption by centipedes is rather rare. Here, we report an incident of saurophagy by the most common Mediterranean scolopendrid, Scolopendra cingulata, on the Aegean wall lizard, Podarcis erhardii. Island particularities may trigger such behaviours that could be more frequent than previously thought.
\end{abstract}

\section{INTRODUCTION}

Scolopendromorpha is an order of predatory chilopods that occur in most parts of the world, with the exception of Antarctica (Bonato and Zapparoli 2011). They mainly feed on other arthropods and laboratory observations have shown a wide spectrum of prey organisms: earthworms, snails, spiders, cockroaches, locusts, beetle and fly larvae, wasps, bees and many other insects (Lewis 1981; Voigtländer 2011). Lewis (1966) examined the gut content of 37 Scolopendra morsitans from Khartoum, Sudan, and found numerous fragments of arthropods, such as spiders, mites, centipedes, flies, beetles, termites and ants. Iorio (2006) observed two cases of predation on the scorpion Euscorpius flavicaudis by Scolopendra cingulata in the forests of the Bouchesdu-Rhône, in France.

However, large scolopendromorphs have also been frequently reported to prey on small vertebrates (McCormick and Polis 1982). In Asia and, most notably, the Americas, their diet may include rats (Clark 1979), bats (Molinari et al. 2005; Srbek-Araujo et al. 2012; Noronha et al. 2015; Lindley et al. 2017), toads (Carpenter and Gillingham 1984), tree frogs (Forti et al. 2007; Folly et al. 2019) and even snakes (Easterla 1975; Mirza and Ahmed 2009; Chiacchio et al. 2017). Saurophagy

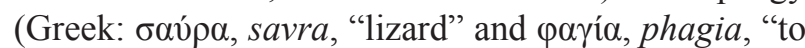
eat what the first part denotes"), lizard consumption, is an atypical feeding behaviour among centipedes. Large, mainly tropical, species may occasionally include lizards in their diet (Lewis 1981; Moura et al. 2015). The rarity of such observations, compared to the consump- tion of mammals or amphibians, could be attributed to the hard saurian scales that are tough to penetrate. In Europe, saurophagy by a centipede has, to the best of our knowledge, been reported just once (Zimić and Jelić 2014). Here, we report a case of a Podarcis erhardii lizard (Reptilia: Squamata: Lacertidae) being consumed by the most common Mediterranean scolopendrid, Scolopendra cingulata (Chilopoda: Scolopendromorpha: Scolopendridae), on Andros Island (Aegean Sea, Greece) (Figure 1).

Podarcis erhardii, the Aegean wall lizard, is a small diurnal lacertid, endemic to the Balkans (Valakos et al. 1999). In Greece, its range covers most of the mainland and the Aegean Islands, excluding Crete and parts of the Peloponnese (Valakos et al. 2008). In the Archipelago, it is the most common lacertid lizard species (Lymberakis et al. 2018). It is mainly an insectivorous species, feeding primarily on coleopterans, orthopterans and arachnids, but expands its diet during the summer months to include ants and fruits (Valakos et al. 1997; Adamopoulou et al. 1999; Brock et al. 2014). Scolopendra cingulata has a widespread distribution that includes northern Africa, western Asia, central and south-eastern Europe and many Mediterranean islands (excluding Sardinia, Corsica and the Balearic Islands) (Simaiakis and Mylonas 2008). In Greece, the species occurs throughout the mainland and on most islands, with the exception of Crete and its satellite islands (Simaiakis et al. 2005). The species is carnivorous and typically feeds on insects, worms, spiders and scorpions, but occasionally may enhance its diet with vertebrate prey, such as small mice (Lewis 1981). Filial cannibal- 


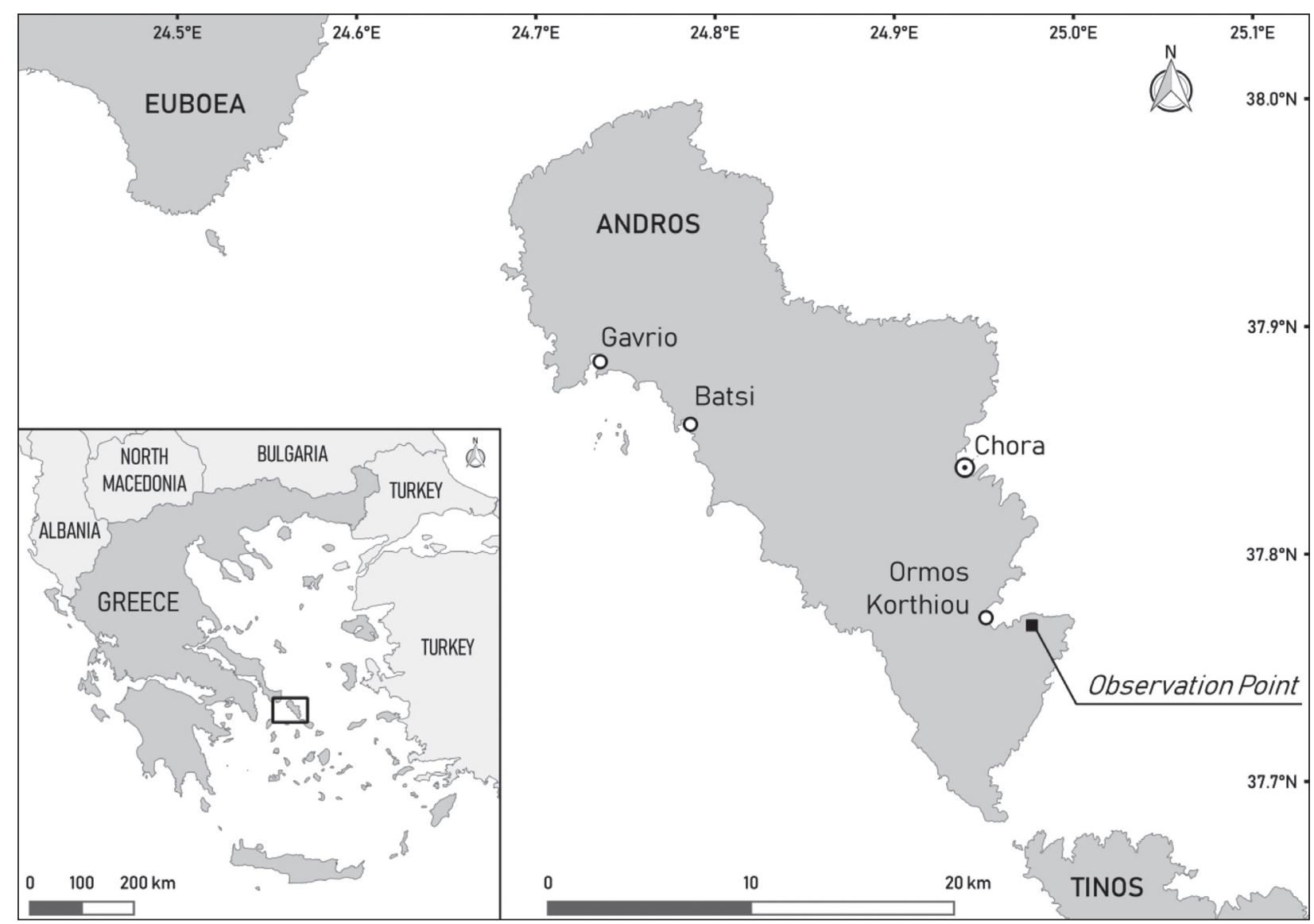

Figure 1. Andros Island in the central Aegean Archipelago, Greece. The black square in the map on the right denotes the exact location where the incident of saurophagy was recorded.

ism has been recently reported (Cabanillas et al. 2019). The Mediterranean banded centipede seizes its prey with its claws and secrets its venom that causes paralysis or death through its forcipules (Lewis 1981).

\section{MATERIALS AND METHODS / RESULTS}

On June $6^{\text {th }}, 2019$, the authors conducted fieldwork at $37.76867^{\circ} \mathrm{N}$ and $24.97687^{\circ} \mathrm{E}$, in the southern part of Andros Island. The landscape in the area consists of phrygana shrubs, punctuated by a dense network of dry stone walls. Around noon, we noticed the tail and rear part of an adult Aegean wall lizard protruding from a crevice at the base of a dry stone wall (Figure 2a). When we attempted to grab the base of the tail and pull the lizard out, we realised that the latter was actually dead, held tightly inside the crevice by a $S$. cingulata. The centipede revealed itself when we dragged the lizard out, refusing to abandon its prey (Figure 2b). Scolopendrids are predators and feed on live animals, but scavenging has been recorded as well (Lewis 1981; Voigtländer 2011). In our case, we believe $S$. cingulata actively preyed on $P$. erhardii. The scales of the lizard had the glossy appearance of those of a live animal and the general condition of the specimen was quite good, so we presumed it was a fresh kill.

\section{DISCUSSION}

This is only the second report of a lizard being predated upon by $S$. cingulata. The first one (Zimić and Jelić 2014) refers to the active predation of a sharp-snouted rock lizard (Dalmatolacerta oxycephala), a lacertid lizard of similar size to $P$. erhardii, in the Dalmatian island of Korčula (Croatia). Our report further supports the notion that $S$. cingulata includes lizards in its diet. As scolopendrids are generally nocturnal predators, whereas most lizards are active during the day, interactions between these two groups are seldom documented (Moura 2015). However, such interactions may not be all that rare, considering most centipedes are adapted to life under the surface (Clark 1979) and may often encounter hiding lizards, particularly during the night, when they are most active and lizards seek shelter.

Interestingly, both reports of saurophagy by $S$. cingulata derive from islands (Zimić and Jelić 2014 and this note). Island life comes with many adaptations to the particularities of insularity (MacArthur and Wilson 1967; Losos and 


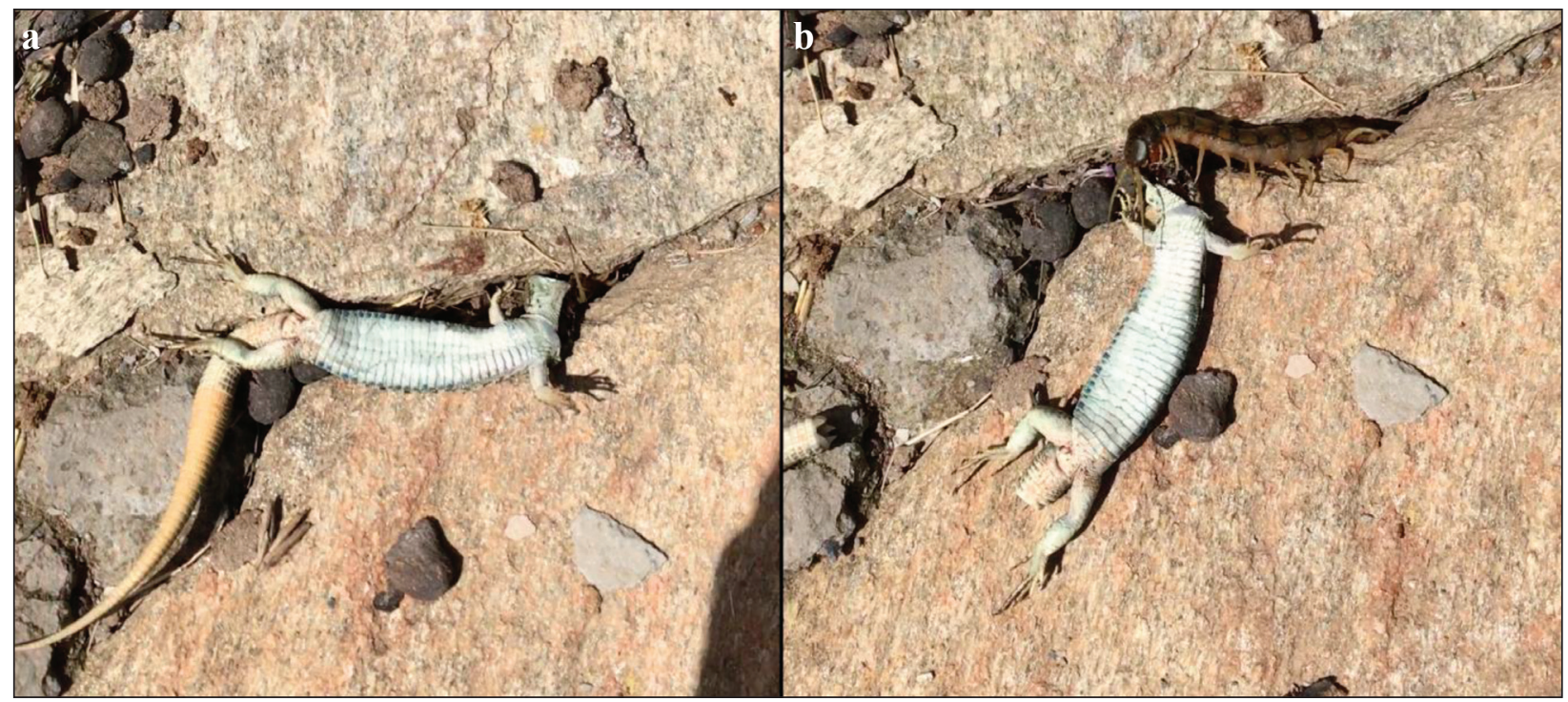

Figure 2. (a). Podarcis erhardii lizard protruding from a crevice in the ground, held tightly by the scolopendrid species Scolopendra cingulata. (b) Scolopendra cingulata revealed itself when the lizard was dragged out, refusing to abandon its prey. (Photos by A. Deimezis-Tsikoutas).

Ricklefs 2009). Animal populations on Mediterranean islands tend to alter their feeding ecology (Pafilis et al. 2019 and references therein), but also their size. This is the case for $S$. cingulata, for which intraspecific variation in body length is high in the Aegean Islands, with many individuals being gigantic (Simaiakis et al. 2011). As a result, roles may change in insular biocommunities and the typical predators (lizards) may instead become food for their invertebrate prey. On Columbretes Islands (Spain), scorpions have been observed to prey upon the Iberian wall lizard (Podarcis hispanicus) (Castilla 1995), while the Mediterranean black widow spider is known to kill and consume the Dalmatian wall lizard (Podarcis melisellensis) on Krk Island in Croatia (Schwammer and Baurecht 1988). Such accounts provide valuable insights on the predator-prey relationships between Mediterranean reptiles and invertebrates, while improving our understanding of the position they occupy in insular food webs.

\section{REFERENCES}

Adamopoulou, C., P. Pafilis, and E. D. Valakos. 1999. Diet composition of Podarcis milensis, P. gaigeae and P. erhardii (Sauria: Lacertidae) during summer. Bonn Zoological Bulletin 48: 275-282.

Bonato, L., and M. Zapparoli. 2011. "Chilopoda - Geographical distribution." In Treatise on Zoology - Anatomy, Taxonomy, Biology. The Myriapoda, edited by A. Minelli, 1: 327-337. Leiden, Germany: Brill.

Brock, K. M., C. M. Donihue, and P. Pafilis. 2014. Novel records of frugivory and ovophagy in Podarcis lizards from East Mediterranean Islands. North-Western Journal of Zoology 10: 223-225.
Cabanillas, D., Á. Albatros, A. García-Ruiz, and F. Rodríguez-Luque. 2019. First observation of filial cannibalism in Scolopendra cingulata Latreille, 1829 (Chilopoda: Scolopendromorpha: Scolopendridae). Bulletin of the British Myriapod \& Isopod Group 31: 26-33.

Carpenter, C. C., and J. C. Gillingham. 1984. Giant centipede (Scolopendra alternans) attacks marine toad (Bufo marinus). Caribbean Journal of Science 20: 71-72.

Castilla, A. M. 1995. Interactions between lizards (Podarcis hispanica atrata) and scorpions (Buthus occitanus) in the Columbretes Islands. Bolleti de la Societat d'Història Natural de les Balears 38: 47-50.

Chiacchio, M., B. S. Nadolski, P. Suwanwaree, and S. Waengsothorn. 2017. Centipede, Scolopendra dawydoffi (Chilopoda: Scolopendridae), predation on an egg-laying snake, Sibynophis triangularis (Squamata: Colubridae), in Thailand. Journal of Insect Behavior 30: 563-566.

Clark, D. B. 1979. A centipede preying on a nestling rice rat (Oryzomys bauri). Journal of Mammalogy 60 (3): 654.

Easterla, D. A. 1975. Giant desert centipede preys upon snake. The Southwestern Naturalist 20: 411.

Folly, H., R. Thaler, G. B. Adams, and E. A. Pereira. 2019. Predation on Scinax fuscovarius (Anura, Hylidae) by Scolopendra sp. (Chilopoda: Scholopendridae) in the State of Tocantins, Central Brazil. Revista Latinoamericana de Herpetología 2 (1): 39-43.

Forti, L. R., H. Z. Fischer, and L. C. Encarnação. 2007. Treefrog Dendropsophus elegans (Wied-Neuwied, 1824) (Anura: Hylidae) as a meal to Otostigmus tibialis Brölemann, 1902 (Chilopoda: Scolopendridae) in the Tropical Rainforest in southeastern Brazil. Brazilian Journal of Biology 67 (3): 583-584. 
Iorio, E. 2006. The scolopendromorph Scolopendra cingulata Latreille, 1829 (Scolopendromorpha, Scolopendridae), a predator of the scorpion Euscorpius (Tetratrichobothrius) flavicaudis (De Geer, 1778) (Scorpiones, Euscorpiidae). Le Bulletin d'Arthropoda 30: 60-62.

Lewis, J. G. E. 1966. The taxonomy and biology of the centipede Scolopendra amazonica in the Sudan. Journal of Zoology 149 (2): 188-203.

Lewis, J. G. E. 1981. The biology of centipedes. Cambridge University Press: Cambridge, UK.

Lindley, T. T., J. Molinari, R. M. Shelley, and B. N. Steger. 2017. A fourth account of centipede (Chilopoda) predation on bats. Insecta Mundi 573: 1-4.

Losos, J. B. and R. E. Ricklefs. 2009. Adaptation and diversification on islands. Nature 457: 830-836.

Lymberakis, P., P. Pafilis, N. Poulakakis, K. Sotiropoulos, and E. D. Valakos. 2018. The Amphibians and Reptiles of the Aegean Sea. In Biogeography and Biodiversity of the Aegean. In honour of Prof. Moysis Mylonas, edited by S. Sfenthourakis, P. Pafilis, A. Parmakelis, N. Poulakakis, and K. A. Triantis, 169-189. Nicosia, Cyprus: Broken Hill Publishers.

MacArthur, R. H., and E. O. Wilson. 1967. The theory of island biogeography. Princeton, USA: Princeton University Press.

McCormick, S., and G. A. Polis. 1982. Arthropods that prey on vertebrates. Biological Review 57: 29-58.

Mirza, Z. A., and J. J. Ahmed. 2009. Note on predation of Calliophis melanurus Shaw, 1802 (Serpents: Elapidae) by Scolopendra sp. Hamadryad 34 (1): 166.

Molinari, J., E. E. Gutiérrez, A. A. Ascenção, J. M. Nassar, A. Arends, and R. J. Márquez. 2005. Predation by giant centipedes, Scolopendra gigantea, on three species of bats in a Venezuelan cave. Caribbean Journal of Science 41 (2): 340-346.

Moura, L. O. G., C. M. S. Machado, A. O. Silva, B. M. Conceição, A. S. Ferreira, and R. G. Faria. 2015. Predation of Ameivulla ocellifera (Spix, 1825) (Squamata: Teiidae) by Scolopendra sp. (Linnaeus, 1758) (Chilopoda: Scholopendridae) in the vegetation of the Caatinga biome, northeastern Brazil. Herpetology Notes 8: 389-391.

Noronha, J. C., L. D. Battirola, A. Chagas-Júnior, R. M. Miranda, R. S. Carpanedo, and D. J. Rodrigues. 2015. Predation of bat (Molossus molossus: Molossidae) by the centipede Scolopendra viridicornis (Scolopendridae) in Southern Amazonia. Acta Amazonica 45 (3): 333-336.
Pafilis, P., G. Kapsalas, P. Lymberakis, D. Protopapas, and K. Sotiropoulos. 2019. Diet composition of the Karpathos marsh frog (Pelophylax cerigensis): what does the most endangered frog in Europe eat? Animal Biodiversity and Conservation 42 (1): 1-8.

Schwammer, H., and D. Baurecht. 1988. Der Karstläufer, Podarcis melisellensis fiumana (Werner, 1891), als Beute der Europäischen Schwarzen Witwe, Latrodectus mactans tredecimguttatus (Rossi, 1970). Herpetozoa 1 (1/2): 73-76.

Simaiakis, S., and M. Mylonas. 2008. The Scolopendra species (Chilopoda: Scolopendromorpha: Scolopendridae) of Greece (E-Mediterranean): a theoretical approach on the effect of geography and palaeogeography on their distribution. Zootaxa 1792: 39-53.

Simaiakis, S., A. Minelli, and M. Mylonas. 2005. The centipede fauna (Chilopoda) of the south Aegean Archipelago (Greece, Eastern Mediterranean). Israel Journal of Zoology 51: 241-307.

Simaiakis, S., S. Giokas, and Z. Korsos. 2011. Morphometric and meristic diversity of the species Scolopendra cingulata Latreille, 1829 (Chilopoda: Scolopendridae) in the Mediterranean region. Zoologischer Anzeiger 250: 67-79.

Srbek-Araujo, A. C. S., M. R. Nogueira, I. P. Lima, and A. L. Peracchi. 2012. Predation by the centipede Scolopendra viridicornis (Scolopendromorpha, Scolopendridae) on roof-roosting bats in the Atlantic Forest of southeastern Brazil. Chiroptera Neotropical 18 (2): 1128-1131.

Valakos, E. D., C. Adamopoulou, P. Maragou, and M. Mylonas. 1997. The food of Podarcis milensis and Podarcis erhardii in the insular ecosystems of the Aegean. In Herpetologia bonnensis, edited by W. Böhme, W. Bischoff, and T. Ziegler, 373-381. Bonn, Germany: Societas Europaea Herpetologica.

Valakos, E. D., P. Maragou, and M. Mylonas. 1999. Geographic distribution. Podarcis erhardii. Herpetological Review 30 (1): 52-53.

Valakos, E. D., P. Pafilis, K. Sotiropoulos, P. Lymberakis, P. Maragou, and J. Foufopoulos. 2008. The Amphibians and Reptiles of Greece. Frankfurt am Main, Germany: Chimaira.

Voigtländer, K. 2011. Chilopoda - Ecology. In Treatise on Zoology - Anatomy, Taxonomy, Biology. The Myriapoda, edited by A. Minelli, 1: 309-325. Leiden, Germany: Brill.

Zimić, A., and D. Jelić. 2014. Interspecific illusions: Underestimation of the power of the Mediterranean banded centipede. Hyla 2014 (1): 27-2. 